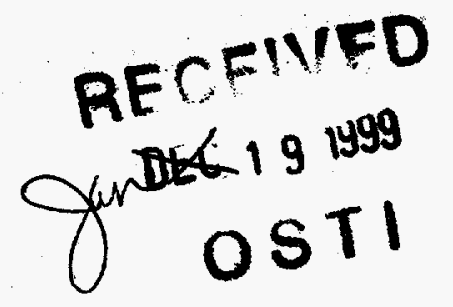

DEPARTMENT OF THE INTERIOR

U.S. GEOLOGICAL SURVEY

$$
\text { USGS-OFR-- } 98-530
$$

PRE-CONSTRUCTION GEOLOGIC SECTION ALONG THE CROSS

DRIFT THROUGH THE POTENTIAL HIGH-LEVEL RADIOACTIVE

WASTE REPOSITORY, YUCCA MOUNTAIN, NYE COUNTY,

NEVADA

Open-File Report 98-530

Prepared in cooperation with the

NEVADA OPERATIONS OFFICE

U.S. DEPARTMENT OF ENERGY, under

Interagency Agreement DE-AI08-97NV12033

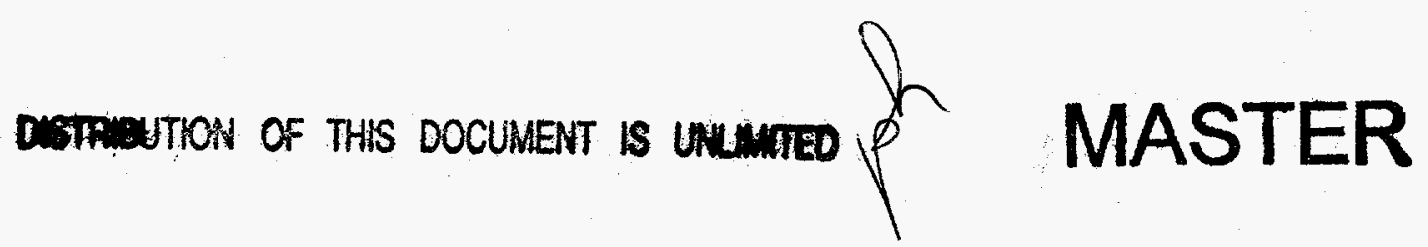




\section{DISCLAIMER}

This report was prepared as an account of work sponsored by an agency of the United States Government. Neither the United States Government nor any agency thereof, nor any of their employees, make any warranty, express or implied, or assumes any legal liability or responsibility for the accuracy, completeness, or usefulness of any information, apparatus, product, or process disclosed, or represents that its use would not infringe privately owned rights. Reference herein to any specific commercial product, process, or service by trade name, trademark, manufacturer, or otherwise does not necessarily constitute or imply its endorsement, recommendation, or favoring by the United States Government or any agency thereof. The views and opinions of authors expressed herein do not necessarily state or reflect those of the United States Government or any agency thereof. 


\section{DISCLAIMER}

Portions of this document may be illegible in electronic image products. Images are produced from the best available original document. 


\section{PRE-CONSTRUCTION GEOLOGIC SECTION ALONG THE CROSS DRIFT THROUGH THE POTENTIAL HIGH-LEVEL RADIOACTIVE WASTE REPOSITORY, YUCCA MOUNTAIN, NYE COUNTY, NEVADA}

By Christopher J. Potter ${ }^{1}$, Warren C. Day ${ }^{1}$, Carma San Juan ${ }^{2}$, Donald S. Sweetkind ${ }^{1}$ and Ronald M. Drake, $\mathrm{II}^{2}$

${ }^{1}$ USGS, Denver, Colorado

${ }^{2}$ Pacific Western Technologies, Ltd., Denver, Colorado

Open-File Report

Prepared in cooperation with the

NEVADA OPERATIONS OFFICE

U.S. DEPARTMENT OF ENERGY, under

Interagency Agreement DE-AI08-97NV12033 
U.S. DEPARTMENT OF THE INTERIOR

BRUCE BABBITT, Secretary

U.S. GEOLOGICAL SURVEY

Thomas J. Casadevall, Acting Director 


\section{CONTENTS}

Abstract

Introduction

Geologic setting

Anticipated geology

Anticipated geologic contributions of the Cross Drift

References cited

\section{PLATES}

Plate 1. Geologic map and pre-construction geologic section along the Cross Drift alignment, Yucca Mountain, Nye County, Nevada

\section{FIGURES}

Figure 1. Index map showing the study area on Yucca Mountain

Figure 2. Map showing generalized geology of the Yucca Mountain site area

CONVERSION FACTORS AND ACRONYMS

\begin{tabular}{lll} 
Multiply & by & To obtain \\
\hline millimeter $(\mathrm{mm})$ & 0.03937 & inch \\
centimeter $(\mathrm{cm})$ & 0.3937 & inch \\
meter $(\mathrm{m})$ & 3.281 & foot \\
kilometer $(\mathrm{km})$ & 0.6214 & mile
\end{tabular}

The following terms and abbreviations also are used in this report.

Ma millions of years old 


\title{
Pre-construction Geologic Section along the Cross Drift through the Potential High-Level Radioactive Waste Repository, Yucca Mountain, Nye County, Nevada
}

By Christopher J. Potter, Warren C. Day, Carma San Juan, Donald S. Sweetkind and Ronald M. Drake, II

\begin{abstract}
As part of the Site Characterization effort for the U.S. Department of Energy's Yucca Mountain Project, tunnels excavated by tunnel boring machines provide access to the volume of rock that is under consideration for possible underground storage of high-level nuclear waste beneath Yucca Mountain, Nevada. The Exploratory Studies Facility, a 7.8$\mathrm{km}$-long, 7.6-m-diameter tunnel, has been excavated, and a 2.8-km-long, 5-m-diameter Cross Drift will be excavated in 1998 as part of the geologic, hydrologic and geotechnical evaluation of the potential repository. The southwest-trending Cross Drift branches off of the north ramp of the horseshoe-shaped Exploratory Studies Facility. This report summarizes an interpretive geologic section that was prepared for the Yucca Mountain Project as a tool for use in the design and construction of the Cross Drift.

The Cross Drift traverses two contrasting structural settings: the little-deformed central block of Yucca Mountain, and the highly deformed Solitario Canyon Fault system. Most of the Cross Drift lies within the central block, in gently east-dipping strata in the middle of the densely welded Miocene Topopah Spring Tuff. The zones of the Topopah Spring Tuff that are expected to be penetrated by the Cross Drift in the central block correspond to the repository host horizon. In the central block, the drift will cross the northern tip of the Ghost Dance Fault and through the discontinuous faults associated with the Sundance Fault. Surface geologic mapping along the trace of the Cross Drift has
\end{abstract}


revealed no faults with detectable offsets greater than $1.5 \mathrm{~m}$, except for the Ghost Dance and Sundance Faults. It is anticipated, however, that minor faults will be encountered in the drift.

The westernmost $300 \mathrm{~m}$ of the Cross Drift will cross the block-bounding Solitario Canyon Fault system, and its immediate hanging-wall and footwall. Fracture intensity in the immediate footwall of the Solitario Canyon Fault system may not be significantly different than fracture intensity in the rock mass in the central block of Yucca Mountain that is hundreds of meters away from the fault system. Through the broad fault zone, the drift probably will penetrate numerous highly brecciated faults that juxtapose diverse pieces of the Miocene Paintbrush Group rhyolites. The drift also is anticipated to penetrate an internally faulted, west-dipping structural block of Paintbrush Group volcanic rocks. In the hanging-wall, the drift is expected to penetrate the base of the Tiva Canyon Tuff, bedded tuffs, and the top of the Topopah Spring Tuff, all within the Paintbrush Group.

\section{INTRODUCTION}

The U.S. Department of Energy is evaluating Yucca Mountain, Nevada as a potential site for underground storage of high-level nuclear waste (fig. 1). The potential nuclear waste repository is planned to be excavated within the densely welded Miocene Topopah Spring Tuff, in the unsaturated zone about $250 \mathrm{~m}$ above the regional groundwater table. The U.S. Geological Survey and U.S. Bureau of Reclamation, in cooperation

with the U.S. Department of Energy and its private contractors, have completed numerous studies to characterize the site's hydrology, geologic framework, geophysics, climate history, and seismic hazards. The geologic part of the site characterization has comprised surface geologic mapping (Scott and Bonk, 1984; Day and others, 1998a,b), detailed fracture analyses (Sweetkind and others, 1997), lithologic logging of boreholes, stratigraphic studies (Buesch and others, 1996), and underground geologic mapping by the U.S. Bureau of Reclamation. 
From 1994 through 1997, a 7.8-km-long, 7.6-m-diameter tunnel, the Exploratory Studies Facility (ESF), was excavated with a tunnel boring machine (TBM) within Yucca Mountain to access the stratigraphic level of the potential repository along its eastern margin (fig. 2). An extensive program of geologic and hydrologic investigations is being carried out within the ESF. The Cross Drift, a 2.8-km-long, 5-m-diameter, TBM-driven tunnel is being excavated during 1998 to provide a more complete characterization of the potential repository volume. The new tunnel complements the ESF studies, the drilling program, and surface-based geologic studies. The planned Cross Drift alignment breaks out of the north ramp of the horseshoe-shaped ESF and trends southwest through the potential repository volume, before bending to the west across the Solitario Canyon Fault system (fig. 2). Although the ultimate configuration of the underground workings is yet to be determined, the nuclear waste would be stored in emplacement drifts, which would be below the Cross Drift (pl. 1), if the repository is constructed according to current (1998) design plans.

This report and the accompanying 1:6,000-scale map and geologic section (pl. 1) provide the geologic context for the Cross Drift. The purposes of this report are to: (1) define the structural style to be encountered in the Cross Drift, based on the surface geology; (2) predict the geology to be encountered in the Cross Drift, based on surface geologic mapping and borehole data; and, (3) summarize geologic analyses that have been completed in support of the underground design and construction components of the Department of Energy Yucca Mountain Project.

Geologic mapping by Lipman and McKay (1965) provided an overview of the structural setting of Yucca Mountain and formed the foundation for selecting Yucca Mountain as a site for further investigation as a potential site for the underground storage of nuclear waste. They delineated the main block-bounding faults and some of the intrablock faults, and outlined the zoned compositional nature of the rhyolite tuffs that underlie Yucca Mountain. Scott and Bonk (1984) published a detailed reconnaissance geologic map of the 
area, which was used to identify the most favorable area at Yucca Mountain in which to

conduct further site-characterization studies. Sawyer and others (1994) provided ${ }^{40} \mathrm{Ar} /{ }^{39} \mathrm{Ar}$ dates for the major tuff units exposed in the area. Simonds and others (1995) compiled evidence on the extent of Quaternary movement on the major block-bounding faults. Buesch and others (1996) described the detailed stratigraphy for the area. Spengler and others $(1993,1994)$ summarized detailed mapping efforts in the vicinity of the Ghost Dance Fault in the central block. Day and others (1998), provided a detailed structural framework for the central block area at a 1:6,000-scale, incorporating 1:2,400-scale bedrock geologic mapping of Potter and others (in press) in the vicinity of the Sundance Fault (pl. 1, fig. 2). The Bureau of Reclamation has produced a series of unpublished fullperiphery maps and detailed line surveys (Sweetkind and others, 1997) that record locations and attributes of joints and faults in the ESF.

\section{GEOLOGIC SETTING}

Yucca Mountain is located within the southern part of the southwestern Nevada volcanic field in an area where a thick section of Tertiary volcanic rocks overlies Paleozoic sedimentary strata (Byers and others, 1976). These Tertiary volcanic rocks record the evolution of at least seven calderas that compose the Timber Mountain-Oasis Valley caldera complex (fig. 1; Sawyer and others, 1994). The volcanic section at Yucca Mountain is composed principally of thick, welded ash-flow sheets that are separated by thinner, silicic lavas, and tuffaceous sedimentary units. Formations of the Paintbrush Group were erupted between 12.8 and 12.7 Ma and form most of the bedrock exposures in the study area (Sawyer and others, 1994; Christiansen and Lipman, 1965; Scott and Bonk, 1984). Yucca Mountain is underlain by two densely welded and devitrified ash-flow tuffs (the Tiva Canyon and Topopah Spring Tuffs) that are separated by a comparatively thin interval of mostly nonwelded, vitric pyroclastic deposits. The Topopah Spring Tuff is the lower of the two thick, devitrified, densely welded ash-flow sheets of the Paintbrush Group and 
contains the potential repository host horizon. The potential repository host horizon comprises the lower nonlithophysal, lower lithophysal, middle nonlithophysal and upper lithophysal zones of the crystal-poor member of the Topopah Spring Tuff (pl. 1). Underlying the Paintbrush Group are several ash-flow tuffs, including the rhyolitic, mostly nonwelded Calico Hills Formation, and the Prow Pass and Bullfrog tuffs belonging to the Crater Flat Group.

The structural geology of Yucca Mountain is dominated by block-bounding faults, which are north-striking normal faults spaced 1 to $4 \mathrm{~km}$ apart. The block-bounding faults commonly have undergone hundreds of meters of down-to-the-west Tertiary displacement of Miocene Paintbrush Group tuffs, with a subordinate component of left-lateral strike-slip motion (Potter and others, 1996). The central block, which includes the site of the potential repository, is bounded by the Solitario Canyon Fault on the west and the Bow Ridge Fault on the east (fig. 2). Between these two block-bounding faults, the Paintbrush Group rocks commonly dip from $4^{\circ}$ to $10^{\circ}$ to the east. The dips of the strata steepen in the hanging-wall areas of the block-bounding faults; for example, strata adjacent to the Bow Ridge Fault dip up to $30^{\circ}$ to the east (Scott and Bonk, 1984; Day and others, 1998).

All but the western end of the Cross Drift lies in the north-central part of the 4-kmwide central block of Yucca Mountain (pl. 1, fig. 2). Within this part of the central block, small amounts of displacement are accommodated along minor intrablock faults. Intrablock faults, as mapped at the surface near the Cross Drift (Day and others, 1998; Potter and others, in press) have 1-15 m of normal displacement, with typical mapped lengths of less than $1 \mathrm{~km}$. In many cases, intrablock faults appear to represent local structural adjustments in response to displacements on the block-bounding faults. In areas of block-margin deformation within a few hundred meters of the block-bounding faults, more intense intrablock faulting is present, especially in the immediate hanging-walls of block-bounding faults. The most prominent intrablock fault in the central block is the steeply west-dipping Ghost Dance Fault (Spengler and others, 1993), which is $4 \mathrm{~km}$ long and has displaced the 
Tiva Canyon Tuff up to $30 \mathrm{~m}$ down-to-the-west, $2.1 \mathrm{~km}$ south of the Cross Drift. The planned alignment of the Cross Drift crosses the northern tip of the Ghost Dance Fault, where stratigraphic displacement mapped at the surface has diminished to zero (pl. 1; fig. 2).

The westernmost $300 \mathrm{~m}$ of the Cross Drift will cross the block-bounding Solitario Canyon Fault system. This fault system comprises numerous fault strands that juxtapose diverse pieces of the Paintbrush Group. It also contains a prominent, internally faulted, west-dipping structural block of volcanic rocks of the Paintbrush Group; such westdipping panels are characteristic of several block-bounding fault systems at Yucca Mountain (Scott and Bonk, 1984; Scott, 1990; Day and others, in press).

\section{ANTICIPATED GEOLOGY}

The text in this section describes specific structures in the vicinity of the Cross Drift, from northeast to southwest. The discussion is tied to the pre-construction geologic section (pl. 1) along the Cross Drift. The following assumptions and conventions were used in construction of the geologic section:

(1) Positions of stratigraphic contacts and unit thicknesses displayed on the geologic section are based on the geologic mapping and on geologic section $\mathrm{A}-\mathrm{A}^{\prime}$ of Day and others (1998). The Yucca Mountain Project three-dimensional geologic framework model (ISM2.0) (R. Clayton, written commun., 1997, Woodward-Clyde Federal Services) corroborates the locations and thicknesses for geologic units in the subsurface.

(2) The dips of the faults are projected from the surface using values measured or inferred from the mapping of Day and others (1998). There are inherent uncertainties of $+/-$ $3^{\circ}$ for many of these dip values, and the dips may vary with depth as well. If the overall dip of a fault between the surface and the Cross Drift is actually $6^{\circ}$ different from that represented in the geologic section, the resulting error in the position of the fault's intersection at the depth of the Cross Drift would be $20-25 \mathrm{~m}$. The magnitude of this 
difference varies, depending on the depth of the drift beneath the surface at a given location.

(3) For convenience, faults are illustrated on the geologic section as being continuous and planar with depth. However, the character (width, number of splays, and even in the direction of dip) of some fault zones may vary considerably with depth.

(4) Faults with offsets of less than $3 \mathrm{~m}$ were not illustrated on the geologic section.

(5) Locations along the trace of the ESF are given in meters from the entrance of the north portal along the centerline of the ESF invert, which is the concrete floor of the ESF tunnel. For example, an ESF station of $19+92$ is $1,992 \mathrm{~m}$ from the north portal. The locations given along the Cross Drift are recorded as the distance from its northeast end, defined by the intersection of its centerline with the centerline of the ESF at the breakout of the Cross Drift from the ESF. For example, a location of $4+80$ is $480 \mathrm{~m}$ along the centerline of the Cross Drift from its intersection with the centerline of the ESF.

The Cross Drift breaks out from the north ramp of the ESF beneath Drill Hole Wash, at ESF station 19+92, in the general vicinity of the Drill Hole Wash Fault (pl. 1; fig. 2). The cumulative stratigraphic throw across two splays of the Drill Hole Wash Fault encountered in the ESF may be as little as $1.2 \mathrm{~m}$. A northern splay of the Drill Hole Wash Fault, penetrated by the ESF between stations $19+02$ and $19+43$, is positioned east of the breakout point of the Cross Drift. Therefore, this northern splay will not be penetrated by the Cross Drift. The southwestern splay of the Drill Hole Wash Fault is likely to be intersected by the Cross Drift at about Cross Drift station $1+30$, beneath Drill Hole Wash. This fault is expected to resemble its exposure in the ESF (ESF Station 22+65), where it is an open and uncemented breccia zone with an apparent offset of at least $1.2 \mathrm{~m}$ down-to-thesouthwest.

The Cross Drift alignment crosses the northern tip of the Ghost Dance Fault at about Cross Drift station $4+80$, which is beneath Wren Wash. Surface mapping (Day and others, 1998 ) shows that displacement of the Tiva Canyon Tuff by the Ghost Dance Fault 
has diminished to zero in this vicinity. At this northern termination of the Ghost Dance Fault, the fault is marked by a $1-\mathrm{m}$ wide, clast-supported breccia zone. A similar breccia zone may be encountered by the Cross Drift.

The Cross Drift will penetrate the Sundance Fault zone (Spengler and others, 1994) between Cross Drift stations $10+70$ and $11+00$. Surface mapping by Potter and others (in press) indicates that the Sundance Fault zone has a $20^{\circ} \mathrm{W}$. - N $30^{\circ} \mathrm{W}$. strike and dips $80^{\circ}-90^{\circ}$ to the northeast. The maximum width of the Sundance Fault zone is about 75 meters and the cumulative northeast-side-down vertical displacement across the fault zone does not exceed $11 \mathrm{~m}$ (Potter and others, in press). On the north side of Purgatory Ridge, directly above the Cross Drift, the Sundance Fault zone has $7 \mathrm{~m}$ of northeast-side-down displacement. Individual fault strands in the Sundance Fault zone are laterally and vertically discontinuous. The displacement is distributed across four splays in the crystalpoor member of the Tiva Canyon Tuff exposed on the slopes, but all of the displacement is taken up by one fault strand that cuts the crystal-rich member of the Tiva Canyon Tuff along the crest of Purgatory Ridge. The fault zone is interpreted to exploit pre-existing cooling joints, so that the width of the zone and the number of splays are controlled by the jointing characteristics of each stratigraphic interval (Potter and others, in press). The limited trace length of the Sundance Fault strongly implies that it dies out with depth. The discontinuous nature of the fault zone and its component splays introduce uncertainty as to the position and amount of offset on this structure at the level of the Cross Drift. For this reason, the Sundance Fault zone is represented with a dashed line at depth on the geologic section (pl. 1).

In the main drift of the ESF, the fault identified as the Sundance Fault (S.C. Beason, written commun., 1998, U.S. Bureau of Reclamation) is a northwest-striking fault with subhorizontal slickenlines with an indeterminate amount of displacement. The fault is part of a population of northwest-striking fractures that is present over several tens of meters of the ESF. Within the ESF, the Sundance Fault and associated structures dip 
steeply to the west, which contrasts with the vertical to steep easterly.dips preserved at the surface. The Sundance Fault location in the ESF underlies the southeast end of the Sundance Fault zone as mapped at the surface (Potter and others, in press). Individual fault strands are discontinuous and appear to have small displacement in this part of the Sundance Fault zone, both in the ESF and at the surface

It is difficult to predict how much stratigraphic displacement will be seen across the Sundance Fault zone in the Cross Drift. There may be as much as 7-11 $\mathrm{m}$ of offset, equal to that mapped at the surface directly above the Cross Drift; this is the area where it has its maximum stratigraphic throw based on surface mapping (Potter and others, in press; Day and others, 1998). Alternatively, the Sundance Fault zone may die out at depth, as suggested above, and the stratigraphic throw mapped across this fault zone in the Cross Drift may be somewhat less than that mapped at the surface.

The various splays of the Sundance Fault zone encountered by the Cross Drift are likely to be brecciated, with breccia zones ranging from $10 \mathrm{~cm}$ to $1 \mathrm{~m}$ in width, if the fault zone resembles the Sundance Fault as mapped at the surface on Purgatory Ridge by Potter and others (in press). The geologic section shows that the contact between the upper lithophysal and middle nonlithophysal zones of the Topopah Spring Tuff is cut by the Sundance Fault zone near the place where the Cross Drift will intersect the Sundance Fault. If so, the intensity of minor faulting in the Sundance Fault zone may be greater in the middle nonlithophysal zone than in the upper lithophysal zone, based upon observation of these zones elsewhere at Yucca Mountain (Sweetkind and others, 1997).

Other than breccia zones in the vicinity of the Drill Hole Wash, Ghost Dance, and Sundance Fault zones, little brecciation and faulting are expected along the part of the Cross Drift that is east of the Solitario Canyon Fault system. In the ESF, faults with minor or indeterminate amounts of offset are present (but not a pervasive structural characteristic) in such relatively undeformed areas. At the surface these structures generally are not exposed well enough to be mapped due to their relatively small amounts of displacement, quality of 
the outcrop, and the general lack of distinct marker horizons. Locally, sufficient outcrop exists to document that faults with minor displacement (less than 1-2 m) are vertically discontinuous in nearly every case.

A structural feature that may possibly be intersected by the Cross Drift west of about station $18+00$ is a zone of closely spaced, subvertical, northwest striking joints within the middle nonlithophysal zone of the crystal-poor member of the Topopah Spring Tuff. Such a zone is exposed in the ESF between stations $42+00$ to $51+50$ (Buesch and Spengler, 1998). Within this portion of the ESF, a very prominent northwest striking joint set is present, with strike directions that range between N. $67^{\circ} \mathrm{W}$. and N. $34^{\circ} \mathrm{W}$. Joints within this zone have an average spacing of about $0.25 \mathrm{~m}$, but locally joints are spaced 0.1 $\mathrm{m}$ apart or less. Joint spacing within this fracture zone is about half that observed within the middle nonlithophysal zone of the crystal-poor member of the Topopah Spring Tuff elsewhere in the ESF (Buesch and Spengler, 1998). Great length, low surface roughness, gentle curvature, and the presence of inferred high-temperature, vapor-phase mineralization along some joint surfaces indicate that these joints originated at least in part as cooling joints, using criteria defined by Throckmorton and Verbeek (1995). Joints within this fracture zone appear to be stratabound within the middle nonlithophysal zone of the Topopah Spring Tuff on the basis of borehole video recordings (Buesch and Spengler, 1998) and observation of zonal contacts within the ESF.

If the boundaries of this zone of joints trend northwest parallel to the strike of the dominant joint set within the zone, the zone of joints could be projected northwest toward the Cross Drift west of about station $18+00$. The northwestern extent of this zone is unknown, and no outcrops of the middle nonlithophysal zone of the crystal-poor member of the Topopah Spring Tuff exist as far north as the trace of the Cross Drift in Solitario Canyon to help constrain interpretations. Even if the fracture zone does extend northwestward to the trace of the Cross Drift, the Cross Drift excavation will have probably descended through the middle nonlithophysal zone into the lower lithophysal zone of the 
Topopah Spring Tuff (at about station $17+00$ ) by that point, and the closely spaced joints would not be observed.

The Cross Drift should pass through the broad, complex Solitario Canyon Fault system (SCFS) between stations $25+50$ and $27+50$. Immediately east of the fault zone in the adjacent footwall of the fault, outcrop observations in Solitario Canyon (S.C. Beason, written commun., 1998, U.S. Bureau of Reclamation) indicate that there may be no increase in fracture intensity in the footwall adjacent on the eastern margin of the SCFS, relative to that in the rock mass in the central block of Yucca Mountain.

A northeast-striking, down-to-the-west normal fault splay diverges into the footwall from the main Solitario Canyon Fault (Day and others, 1998) and crosses the alignment of the Cross Drift. Where exposed in the steep west-facing slope of Solitario Canyon, this fault dies out upward and represents a growth fault splay of the Solitario Canyon Fault that was active prior to and possibly during emplacement of the 12.7 Ma Tiva Canyon Tuff (Day and others, 1998). Nonwelded tuffs and bedded tuffaceous units that lie between the Topopah Spring and Tiva Canyon tuffs thicken across the fault, indicating motion along of the fault during deposition of the units. At the level of the Cross Drift, this footwall splay will probably be positioned only about 10-20 m east of the eastern edge of the fault zone itself, at about station $25+50$, as it merges with the main fault at depth.

At the surface, the north-striking SCFS is bounded on its eastern side by a fault with prominent scarps that dip about $70^{\circ}-75^{\circ}$ to the west. West of this fault, the fault system consists of numerous fault splays and abundant breccia, and the drift will pass through fault blocks representing diverse parts of the Topopah Spring Tuff. The fault zone is expected to narrow with depth, by analogy with other faults at Yucca Mountain, such as the Ghost Dance Fault and the prominent fault exposed on Busted Butte (Day and others, in press; Scott and Bonk, 1984), and by analogy with well-documented normal faults elsewhere. The pre-Tiva Canyon Tuff nonwelded tuffs are expected to be present in the hanging-wall, as shown on the extreme western end of the geologic section (pl. 1). The 
cumulative stratigraphic throw across the SCFS, where crossed by the Cross Drift, appears to be about $300 \mathrm{~m}$ down-to-the-west.

At the surface, the easternmost part of the SCFS consists of numerous fault splays along which various volcanic units of the Paintbrush Group are juxtaposed. This zone is essentially tectonically mixed, although in this part of the SCFS, brecciated lenses of a single distinct lithology are large enough to be represented at a 1:6,000 map scale. The tectonically mixed zone is several tens of meters wide at the surface, but it is expected to be much narrower where encountered in the Cross Drift, because the fault system is expected to narrow with depth.

West of the tectonically mixed zone, a west-dipping structural block is mapped over a $3 \mathrm{~km}$ length in the SCFS (Day and others, 1998). The west-dipping panel, essentially bisected by the Cross Drift, is only intermittently exposed, being largely covered by Quaternary alluvium and colluvium. Map patterns require significant internal faulting within parts of this west-dipping panel (Day and others, 1998). At the surface, strata in the west-dipping structural block consist mainly of upper parts of the Tiva Canyon Tuff, although exposures of pre-Pah-Canyon Tuff (bt2) near the surface projection of the Cross Drift alignment require the presence of the steeply dipping fault that should break the panel into two blocks. This inferred fault is projected to intersect the Cross Drift at about $26+50$. The combined widths of the west-dipping structural blocks at the level of the Cross Drift are expected to be about $100 \mathrm{~m}$.

At the level of the Cross Drift, the densely welded, middle part of the crystal-poor member of the Topopah Spring Tuff should be present in the west-dipping blocks. Although the geologic section does not show any Tiva Canyon Tuff within the SCFS at the level of the Cross Drift, this unit may be present given the complexities of the fault zone at the surface. Across the entire width of the SCFS, there are few outcrops due to cover by Quaternary surficial deposits. Therefore, it is likely that the number of fault splays is 
under-represented on the geologic section, both in the tectonically mixed zone and in the west dipping structural block.

The western bounding fault of the SCFS is concealed beneath Quaternary cover at the surface, so its location is approximate; for this reason the fault is represented by a dashed line on the geologic section.

\section{ANTICIPATED GEOLOGIC CONTRIBUTIONS OF THE CROSS DRIFT}

From a geologic perspective, the Cross Drift will serve three basic purposes: (1) It will provide abundant new data on the characteristics of the repository host horizon; (2) it will test how accurately surface mapping may be used to determine subsurface structure; and (3) it will provide an unparalleled opportunity to investigate a block-bounding fault system at depth.

Fracture characteristics of the lower part of the repository host horizon (lower lithophysal zone and lower nonlithophysal zone of the crystal-poor member of the Topopah Spring Tuff; pl. 1) are not well known. This is because only the upper part of the repository host horizon (the upper lithophysal zone, middle nonlithophysal zone, and the top of the lower lithophysal zone of the crystal-poor member of the Topopah Spring Tuff; pl. 1) is penetrated by the ESF, and no surface-based fracture studies have been carried out in units corresponding to the lower repository host horizon. The Cross Drift will allow detailed characterization of the fracturing in the lower part of the repository horizon - data which are needed for repository design and performance assessment models.

The Cross Drift may also provide a test of the extent of the northwest-striking intensely fractured zone that was encountered between stations $42+00$ to $51+50$ in the ESF. If this zone is present in the Cross Drift, this would imply that a large volume of the repository host horizon is affected by closely spaced jointing. As noted above, the zone may not be present in the Cross Drift, as observations in the ESF and in boreholes indicate that it is stratabound in the middle nonlithophysal zone of the crystal-poor member of the 
Topopah Spring Tuff (Buesch and Spengler, 1998), and it projects into the Cross Drift in a position where the drift will be below this horizon.

Like the ESF, the Cross Drift will test how accurately surface mapping predicts structures at the repository level. The South Ramp of the ESF was excavated along the line of one of the geologic sections (C-C') produced to accompany the 1:6000-scale geologic map of the central block (Day and others, 1998). The pre-construction geologic section proved to be a reliable guide to the geology encountered by the ESF South Ramp, with minor discrepancies occurring only in one complexly faulted area. In the same way, the pre-construction geologic section (pl. 1) may be compared to geology encountered in the Cross Drift as construction proceeds. As described above, the Cross Drift is expected to traverse two contrasting structural settings: the relatively undeformed central block of Yucca Mountain, and the highly deformed SCFS. Sweetkind and others (1996) summarized possible reasons for mismatches between geology mapped at the surface, and geology mapped in underground excavations, even in relatively undeformed areas of Yucca Mountain. The specific structures encountered along the Cross Drift will vary from those predicted here, because (1) this geologic section and report only take into account faults with less than three meters of offset, and numerous smaller faults are likely to be penetrated by the Cross Drift, even in the relatively undeformed part of the central block; and (2) fault patterns in the intrablock Sundance Fault zone are sufficiently discontinuous, and fault patterns in the block-bounding SCFS are sufficiently complex, that there will undoubtedly be local discrepancies between the anticipated conditions and the actual geology of the Cross Drift.

The depiction of the SCFS in plate 1 represents a logical projection of surface geology to depth. Because of the inherent complexity of the fault zone, and the scarcity of outcrops along the floor and lower slopes of Solitario Canyon, the actual geology encountered in the Cross Drift will not precisely match the geologic section across the SCFS. However, the Cross Drift will test some specific geologic characteristics of the 
SCFS that are shown by the geologic section. These include the downward narrowing of the fault zone, the presence of a highly faulted, tectonically mixed zone in the eastern part of the fault system, and the presence of a less-faulted, west-dipping block in the western part of the fault system. 


\section{REFERENCES CITED}

Buesch, D.C. and Spengler, R.W., 1998, Character of the middle nonlithophysal zone of the Topopah Spring Tuff at Yucca Mountain: High Level Radioactive Waste Management, Proceedings of the 1998 International Conference, American Nuclear Society, La Grange Park, Ill., p. 16-23.

Buesch, D.C., Spengler, R.W., Moyer, T.C., and Geslin, J.K., 1996, Proposed stratigraphic nomenclature and macroscopic identification of lithostratigraphic units of the Paintbrush Group exposed at Yucca Mountain, Nevada; U.S. Geological Survey Open-File Report 94-469, 47p.

Byers, F.M., Jr., Carr, W.J., Orkild, P.P., Quinlivan, W.D., and Sargent, K.A., 1976, Volcanic suites and related cauldrons of Timber Mountain-Oasis Valley caldera complex, southern Nevada: U.S. Geological Survey Professional Paper 919, 69p.

Christiansen, R.L., and Lipman, P.W., 1965, Geologic map of the Topopah Spring Northwest Quadrangle, Nye County, Nevada: U.S. Geological Survey Geologic Quadrangle Map GQ-444, 1:24,000-scale.

Day, W.C., Dickerson, R.P., Potter, C.J., Sweetkind, C.A., San Juan, C.A., Drake, R.M., II, and Fridrich, C.J., 1998a, Geologic map of the Yucca Mountain area, Nye County, Nevada: U.S. Geological Survey Miscellaneous Investigations Series map I-2627, scale 1:24,000.

Day, W.C., Potter, C.J., Sweetkind, D.S., Dickerson, R.P., and San Juan, C.A., 1998b, Bedrock geologic map of the central block area, Yucca Mountain, Nevada; U.S. Geological Survey Miscellaneous Investigations Map I-2601, scale 1:6,000. Lipman, P.W., and McKay, E.J., 1965, Geologic map of the Topopah Spring SW Quadrangle, Nye County, Nevada; U.S. Geological Survey Geologic Quadrangle Map GQ-439, scale 1:24,000. 
Potter, C.J., Day, W.C., and Sweetkind, D.S., 1996, Structural evolution of the potential high-level nuclear waste repository site at Yucca Mountain, Nevada: Geological Society of America Abstracts with Programs, v. 28, no. 7, p. A-191.

Potter, C.J., Dickerson, R.P., and Day, W.C., in press, Nature and continuity of the Sundance Fault, Yucca Mountain, Nevada: U.S. Geological Survey Open-File Report 98-266, scale 1:2,400.

Sawyer, D.S., Fleck, R.J., Lanphere, M.A., Warren, R.G., Broxton, D.E., and Hudson, M.R., 1994, Episodic caldera volcanism in the Miocene southwestern Nevada volcanic field: revised stratigraphic framework, ${ }^{40} \mathrm{Ar} r^{39} \mathrm{Ar}$ geochronology, and implications for magmatism and extension; Geological Society of America Bulletin, v.106, n.10, p. 1304-1318.

Scott, R.B., 1990, Tectonic setting of Yucca Mountain, southwest Nevada, in Wernicke, B.P., ed., Basin and Range extensional tectonics near the latitude of Las Vegas, Nevada: Boulder, Colorado, Geological Society of America Memoir 176, p. 251282.

Scott, R.B., and Bonk, Jerry, 1984, Preliminary geologic map of Yucca Mountain, Nye County, Nevada, with geologic sections; U.S. Geological Survey Open File Report $84-494,1: 12,000$.

Simonds, F.W., Whitney, J.W., Fox, K.F., Ramelli, A.R., Yount, J.C., Carr, M.D., Menges, C.M., Dickerson, R.P., and Scott, R.B., 1995, Map showing fault activity in the Yucca Mountain area, Nye County, Nevada; U.S. Geological Survey Miscellaneous Investigations Map I-2520, scale 1:24,000.

Spengler, R.W., Braun, C.A., Linden, R.M., Martin, L.G., Ross-Brown, D.M., and Blackburn, R., 1993, Structural character of the Ghost Dance fault, Yucca Mountain, Nevada; High Level Radioactive Waste Management, Proceedings of the Fourth International Conference, American Nuclear Society, v. 1, p. 653-659. 
Spengler, R.W., Braun, C.A., Martin, L.G., and Weisenberg, C.W., 1994, The Sundance fault -- a newly recognized shear zone at Yucca Mountain, Nevada: U.S. Geological Survey Open-File Report 94-49, 11 p.

Sweetkind, D.S., Beason, S.C, Potter, C.J., Lung, R., Day, W.C., and Barr, D., 1996, Correlation between surface and subsurface features at Yucca Mountain, Nye County, Nevada: Geological Society of America Abstracts with Programs, v. 28, no. 7 , p. A-521.

Sweetkind, D.S., Williams-Stroud, S., and Coe, J., 1997, Characterizing the fracture network at Yucca Mountain, Nevada, Part 1. Integration of field data for numerical simulations: in, Hoak, T.E., Klawitter, A.L., and Blomquist, P.K., eds., Fractured Reservoirs: Characterization and Modeling: Rocky Mountain Association of Geologists 1997 Guidebook, p. 185-196.

Throckmorton, C.K., and Verbeek, E.R., 1995, Joint networks in the Tiva Canyon and Topopah Spring Tuffs of the Paintbrush Group, southwestern Nevada: U.S. Geological Survey Open File Report 95-2, 179 pp.

\section{FIGURE CAPTIONS}

Figure 1. Study area showing regional distribution of caldera structures near Yucca Mountain, Nevada. Modified from Sawyer and others, (1994, fig. 1)

Figure 2. Approximate boundary of map area shown in plate 1, relative to the alignment of the Exploratory Studies Facility, the Cross Drift alignment, bedrock exposures and selected faults at Yucca Mountain. 


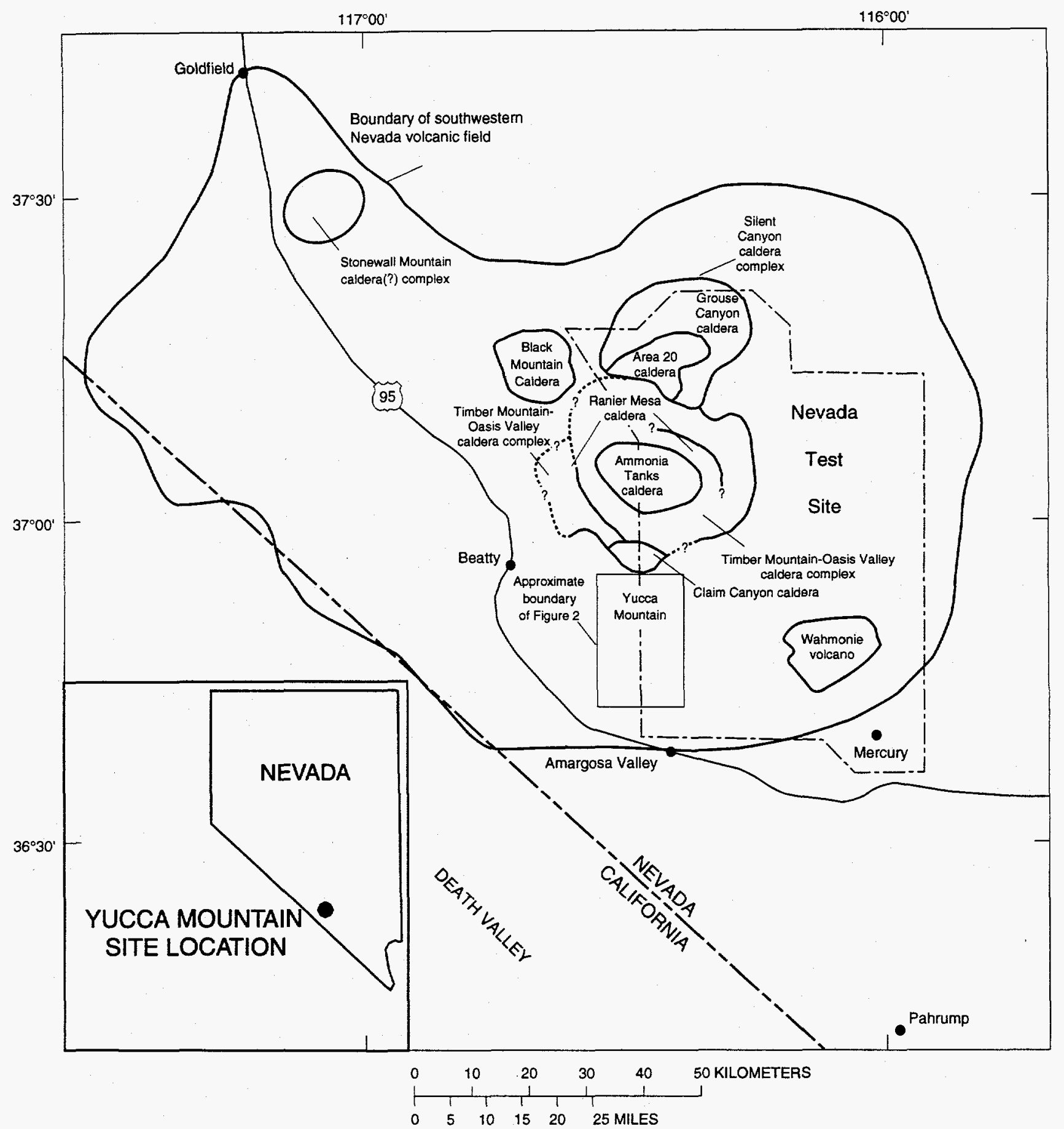

Figure 1. Study area showing the regional distribution of caldera structures near Yucca Mountain, Nye County, Nevada. Modified from Sawyer and others (1994, fig. 1). 


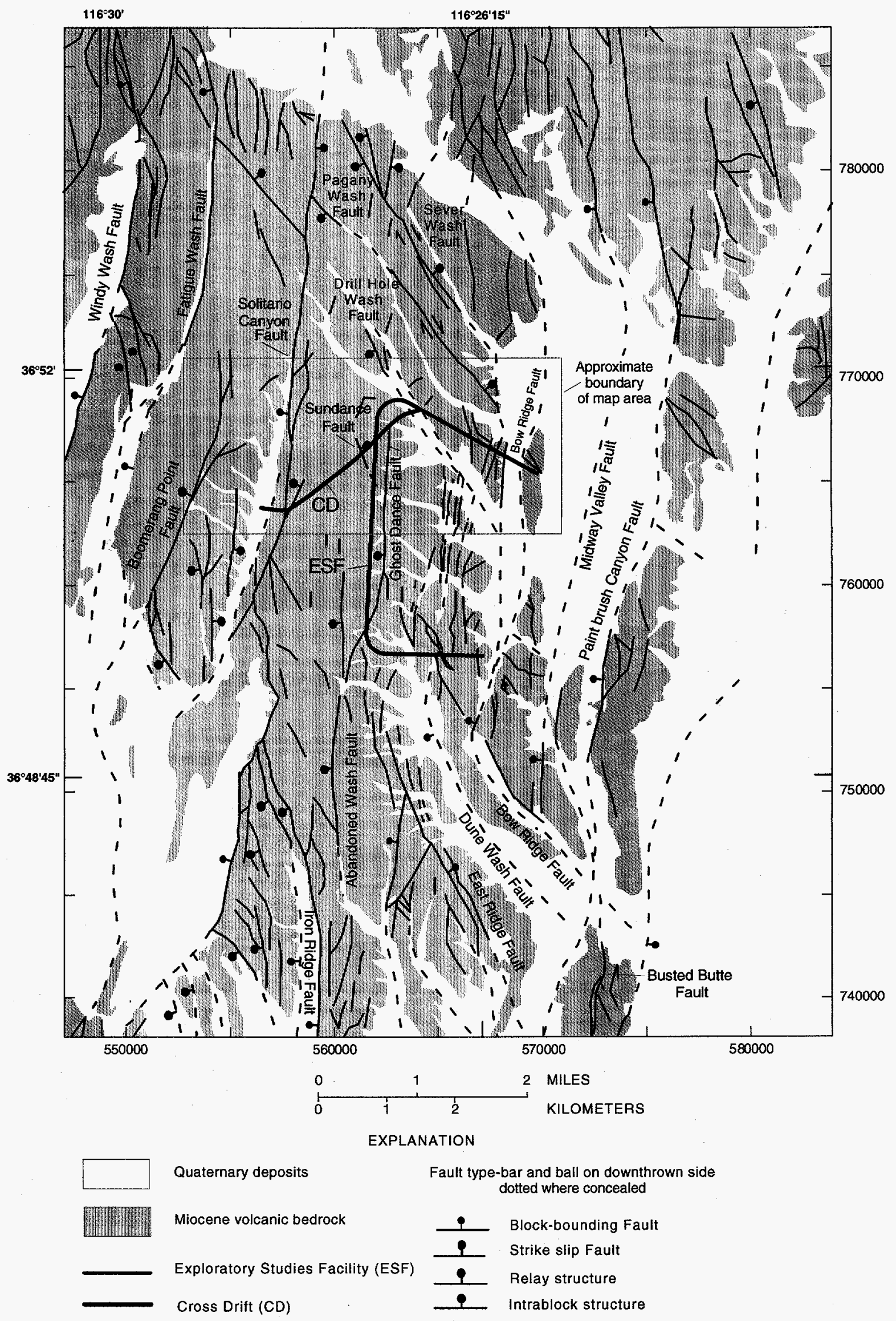

Figure 2. Approximate boundary of map area shown in plate 1, relative to the alignment of the Exploratory Studies Facility, the Cross Drift alignment, bedrock exposures and selected faults at Yucca Mountain. 


\section{NOTICE}

Page(s) size did not permit electronic reproduction. Information may be purchased by the general public from the National Technical Information Service, U.S. Department of Commerce, Springfield, VA 22161 (Area Code 703-487-4650). DOE and DOE contractors may purchase information by contacting DOE's Office of Scientific and Technical Information, P.O. Box 62, Oak Ridge, TN 37831, Attn: Information Services (Area Code 423-576-8401). 